NBER WORKING PAPER SERIES

\title{
PUBLICATION, COMPENSATION, AND THE PUBLIC AFFAIRS DISCOUNT: DOES GENDER PLAY A ROLE?
}

\author{
Lori L. Taylor \\ Kalena E. Cortes \\ Travis C. Hearn \\ Working Paper 26022 \\ http://www.nber.org/papers/w26022 \\ NATIONAL BUREAU OF ECONOMIC RESEARCH \\ 1050 Massachusetts Avenue \\ Cambridge, MA 02138 \\ June 2019
}

Special thanks for helpful comments and suggestions from Jeff Denning, Joanna Lahey, and Abigail Payne as well as the conference and seminar participants at the Association for Education Finance and Policy and Texas A\&M's Bush Schools Quantitative Brown Bag Series. The authors thank Adria Escobedo and Tate Cannon who provided outstanding research assistance. Any errors are attributable to the authors. Institutional support from Texas A\&M's Bush School of Government and Public Service is gratefully acknowledged. The views expressed herein are those of the authors and do not necessarily reflect the views of the National Bureau of Economic Research.

NBER working papers are circulated for discussion and comment purposes. They have not been peer-reviewed or been subject to the review by the NBER Board of Directors that accompanies official NBER publications.

(C) 2019 by Lori L. Taylor, Kalena E. Cortes, and Travis C. Hearn. All rights reserved. Short sections of text, not to exceed two paragraphs, may be quoted without explicit permission provided that full credit, including $(\odot)$ notice, is given to the source. 
Publication, Compensation, and the Public Affairs Discount: Does Gender Play a Role?

Lori L. Taylor, Kalena E. Cortes, and Travis C. Hearn

NBER Working Paper No. 26022

June 2019

JEL No. J01,J16,J30,J31

\section{ABSTRACT}

This paper presents on three new styled facts: first, schools of public affairs hire many economists; second, those economists are disproportionately female; and third, salaries in schools of public affairs are, on average, lower than salaries in mainline departments of economics. We seek to understand the linkage, if any, among these facts. We assembled a unique database of over 2,150 faculty salary profiles from the top 50 Schools of Public Affairs in the United States as well as the corresponding Economics and Political Science departments. For each faculty member we obtained salary data to analyze the relationship between scholarly discipline, department placement, gender, and annual salary compensation. We found substantial pay differences based on departmental affiliation, significant differences in citation records between male and female faculty in schools of public affairs, and no evidence that the public affairs discount could be explained by compositional differences with respect to gender, experience or scholarly citations.

Lori L. Taylor

Texas A\&M University

College Station, TX 77843

lltaylor@tamu.edu

Kalena E. Cortes

The Bush School

Texas A\&M University

4220 TAMU

1049 Allen Building

College Station, TX 77843

and IZA

and also NBER

kcortes@tamu.edu
Travis C. Hearn

Texas A\&M University

College Station, TX 77843

thearn171@gmail.com 


\section{INTRODUCTION}

Salary equity studies have long been used to illuminate pay disparities among higher education faculty based on gender (e.g., Ginther and Hayes, 2003); race and ethnicity (e.g., Webber and Gonzales Canche, 2015); organizational loyalty (e.g., Barbezat, 2004; Masakure, 2016), and scholarly discipline (e.g., Ehrenberg, McGraw, and Mrdjenovic, 2006; Curtis and Kisielewski, 2015). Our study contributes to the literature by disentangling the contributions of discipline, departmental affiliation and gender in faculty pay differentials for schools of public affairs.

Three key observations motivate our analysis. First, we observe that schools of public affairs hire many economists. Second, we observe that those economists are disproportionately female. Finally, we observe that salaries in schools of public affairs are, on average, lower than salaries in mainline departments of economics. We seek to understand the linkage, if any, among these three new styled facts.

Using various data sources, we assembled a unique database of over 2,150 faculty salary profiles from the top 50 Graduate Schools of Public Affairs in the United States as well as the corresponding Economics and Political Science departments in their home universities. For each faculty member we collected compensation data to analyze the relationship between field of specialization, department placement, and annual salary compensation. In addition, we also control for measures of scholarly productivity, such as, citation counts, h-indices, and i10-indices.

There are a couple of key takeaways from our analysis here. First, we found substantial pay differences based on departmental affiliation. Economists in schools of public affairs were paid at a significant discount compared to their counterparts employed in traditional departments of economics. Second, the public affairs discount could not be explained by compositional differences. Controlling for gender, experience and various indicators of research productivity only 
widened the salary gap between economics departments and schools of public affairs. Lastly, we found evidence that citation records differed by gender, discipline and departmental affiliation; and that salary differences between male and female faculty members were not statistically significant once these differences in citation records were taken into account. We found no evidence that the return to citations was systematically higher (or lower) for male than for female faculty members in the institutions of higher education under analysis.

\section{RELEVANT LITERATURE}

The economics literature includes a remarkable number of salary analyses in the higher education contexts. Nearly all of these studies are at least loosely based on hedonic wage models in which the individual's salary is a function of worker characteristics, job characteristics and location characteristics. ${ }^{1}$ Most of these studies focus on quantifying faculty salary differences by some demographic of interest, typically by gender, race/ethnicity or scholarly discipline. Many focus exclusively on salary differentials within economics.

One of the key challenges in those analyses of faculty salary has been the measurement of productivity. Common measures of research productivity include: numbers of publications (Ginther, 2003; Barbezat, 2004; Umbach, 2007; Binder et al., 2010; Renzulli, Reynolds, Kelly, and Grant, 2013; Tuckman and Tuckman, 1976); numbers of citations (Hamermesh, Johnson and Weisbrod, 1982; Gibson, Anderson, and Tressler, 2017; Gibson and Burton-McKenzie, 2017; Hamermesh, 2018) or grant dollars received (Binder et al., 2010; Renzulli et al., 2013). Common measures of teaching productivity include: numbers of teaching awards (Carlin et al., 2013);

\footnotetext{
${ }^{1}$ For a recent review of the higher education literature, see Gibson, Anderson and Tressler (2017) and Hamermesh (2018). For a more general review of the salary equity literature, see Blau and Kahn (2017).
} 
numbers of instructional preparations (Binder et al., 2010); numbers of classes taught (Renzulli et al., 2013); or percent time in teaching (Umbach, 2007).

Of keen interest (at least to economists) have been studies documenting and explaining salary premia for economists vis-à-vis faculty in other academic disciplines. Academic economists enjoy some of the highest average salaries among university faculty. Ehrenberg, McGraw, and Mrdjenovic (2006) found that, at the full professor level, only faculty in engineering and computer science programs earn more than those in economics departments. More recently, Curtis and Kisielewski (2015) found that professors' salaries in economics exceeded those of their social scientist peers in sociology, anthropology, political science and government at each of the assistant, associate, and full professor ranks. For the period of 2002 through 2016, salaries of economists also grew at a faster rate than any their other social science counterparts, rising twice as quickly as anthropology and political science and at three times the rate of sociology for new assistant professors in particular (Curtis and Kisielewski, 2015).

There are several reasons why academic economists enjoy such a salary premium over their colleagues in other social sciences. Human capital theory predicts that workers with similar characteristics - such as professors with similar degrees, responsibilities, and years of experience—will receive similar compensation while workers with dissimilar characteristics will receive dissimilar compensation (e.g., Park, 2012). Even though their teaching tasks might be similar to those of other academics, economists could earn a premium based on their comparative advantage in producing specific, highly-valued academic products. Freeman (1999) argued that economics, with more powerful analytic tools, stronger students (i.e., based on Graduate Record Examinations [GRE] scores), and more mathematically demanding curricula than in sociology or political science, was "the strongest social science" and therefore commanded the highest wages. 
Alternatively, external labor market pressure could account for differences in salary. Economists enjoy unique access to high-value alternative sources of income, such as consulting fees, private investment, and corporate board membership (Fourcade, Ollion, and Algan, 2015), which suggest a high earnings potential for economists who choose to pursue opportunities outside academia. Relatively high wages for economics faculty are therefore justified because universities must compete with the demand for economists in the non-academic labor market (Boyle, 2008; Ehrenberg, 2004b; Buchanan and Tollison, 1981).

On the other hand, some researchers attribute the higher salaries in economics, at least in part, to the male-dominated nature of the discipline (Bellas, 1994; Bellas, 1997; Smart, 1991; Perna, 2003). Researchers have found evidence that female salaries in higher education are systematically below those of males (e.g., Ginther and Hayes, 2003; Ginther and Kahn, 2004; Umbach, 2007) even after controlling for differences in experience and productivity. To the extent that this bias persists, salaries could be higher in economics simply because there are fewer women in the profession.

The disproportionately male composition of economics departments may also exert an influence on pay through citation practices. Dion, Sumner, and Mitchell (2018) find that male scholars not only cite other male scholars more often than they cite female scholars, but are also more likely to cite themselves than are female scholars. In economics specifically, male-authored papers are cited at higher rates than either female-authored papers or mixed-authorship papers (Ferber and Brün, 2011). Considering that the marginal value of a citation may be as high as $\$ 1,300$ per year (Diamond Jr., 1986), gendered citation practices can result in disproportionate financial and career rewards for scholars in male-dominated subfields of social science (Dion, Sumner, and Mitchell, 2018). 
Thus, the literature suggests that gender composition could at least partially explain the salary gap between economics departments and schools of public affairs. If more female academic economists choose to pursue careers in schools of public affairs, we might expect lower pay for economists in those fields due to a greater proportion of women on the faculty.

Much of the research examining faculty salary dispersion between disciplines relies heavily on survey data and very few to date rely on administrative university-level faculty data. ${ }^{2}$ Thus, our study contributes to this literature by analyzing a uniquely assembled dataset of over 2,150 faculty salary profiles from the top 50 Graduate Programs in Public Affairs in the United States and their corresponding Economics and Political Science departments at those universities, rather than survey data. ${ }^{3}$ Unlike surveys conducted by groups such as the American Association of University Professors (Ehrenberg, 2004a) or American Political Science Association (Claypool et al., 2017), the multi-institutional faculty-level data in our study allows us to specifically distinguish faculty by their discipline. For each faculty member we concatenated compensation data to analyze the relationship between specialization, department placement, and salary. When possible we also collected information of the faculty's level of productivity as measured by their citation counts, hindices, and i10-indices.

\footnotetext{
${ }^{2}$ Only a small number of studies about salary dispersion within or between departments use university-level faculty salary data, and these typically use data from only a single university or a small sample (e.g., Boudreau et al., 1997; Volk, Slaughter, and Thomas, 2001; Hilmer, Hilmer, and Lush, 2012).

${ }^{3}$ Several studies (Fairweather, 1995; Umbach 2007, 2008) utilize the National Survey of Postsecondary Faculty (NSOPF), administered by the National Center for Education Statistics. Friedman (1991) conducted a telephone survey of department heads at public administration programs, one element of which aimed to determine how many economists were employed by public affairs programs. The Carnegie Survey of Faculty also appears in the Langton and Pfeffer (1994) study about labor market characteristics, while Gomez-Mejia and Balkin (1992) opted to design their own survey.
} 


\section{DATA SOURCES AND DESCRIPTIVE STATISTICS}

We approach our inquiry into the relative salaries of economists from the perspective of a leading school of public affairs. Thus, we began our analysis by identifying a sampling frame based on the universities housing the top graduate programs in public affairs, according to the U.S. News and World Report (USNWR) rankings for 2018. We chose to limit our search to schools of public affairs in the top 50 of the USNWR rankings to ensure a sufficiently large sample while maintaining a focus on sectoral leaders. Once we identified the leading schools of public affairs, we sought publicly available faculty salary data for each of the corresponding colleges or universities. No private institutions of higher education (IHEs) meeting the search criteria voluntarily published salary data publicly. However, we extracted payroll information for the 33 public IHEs from numerous sources, including university and state government websites, nonprofit organizations committed to transparency, and newspapers or other periodicals in the state of interest. If salary data were unpublished, we submitted open records requests to obtain the soughtafter data). See Table 1 for descriptive statistics

[Table 1 about here]

Not all of these original datasets provided the same information. Each publicly-available payroll dataset included name, title, and salary. However, some datasets provided multiple figures for salary, while others provided only one. Some datasets also provided full-time equivalent (FTE) numbers, but not others. The reporting years varied. Where available, we calculated the most recent salary using FTE information for each faculty. However, we recognize that there are institutionspecific differences in the measurement of salary. As a result, our analyses will include IHE fixed effects in all estimated regression models. 
For each of the 33 IHEs, we retained salary data for three departmental types: public affairs, economics, and political science. We restricted the sample to regular faculty members at the assistant, associate and full professor levels. Thus, we excluded adjunct, visiting, distinguished, and emeritus positions, as well as administrative faculty such as deans or department heads.

The next step in compiling a useful dataset required visiting each university's website and matching information from the faculty directory with the names listed in the dataset for that institution. We coded each faculty member's department using a series of indicator variables based on the faculty department website where their profile appeared. To determine a faculty member's sex, highest degree held, year of degree and academic discipline, we examined information available in their faculty biography or the curriculum vitae (CV) posted on their faculty page. If such information were unavailable, we performed a broader Internet search to locate any missing details about an individual, leading either to a personal website or to their $\mathrm{PhD}$ information posted with an affiliated organization.

We constructed indicator variables for whether or not a faculty member was an economist or a political scientist based on the field in which they obtained their $\mathrm{PhD}$ and their departmental affiliations. Faculty members with a degree in economics (including variants like agricultural economics or econometrics) were classified as economists, as were all faculty members in departments of economics. Faculty members with degrees in political science, government, foreign affairs or international relations were classified as political scientists, as were all faculty members in departments of political science. Individuals with degrees in political economy or "political science and economics" were assigned a one for both the economist indicator variable and the political scientist indicator variable. ${ }^{4}$ If professors listed only their PhD-granting institution,

\footnotetext{
${ }^{4}$ The analysis was not sensitive to this coding choice because the number of individuals was small.
} 
without any additional $\mathrm{PhD}$ information and were not affiliated with a traditional economics or political science department, we coded their field of degree as missing. In addition, if the available online resources indicated that the faculty member did not hold a PhD, then he or she was excluded from the analysis. ${ }^{5}$ We coded as missing any educational attainment data that could not be located online, which occurred most often when a professor did not provide a CV publicly. Some faculty advertised their $\mathrm{CV}$ as available on request, but we did not send any $\mathrm{CV}$ requests for this study, opting to use only publicly posted information.

Because we were interested in analyzing differences in salary by gender, we also collected the information on faculty's sex from the same public sources as discipline and department information. Then, we coded each faculty member as male or female based on our familiarity with the individuals, photographs posted to their faculty profile or personal website, and any gendered third-person pronouns included in their own biographical materials.

Finally, we followed Hamermesh (2018) and measured faculty productivity using citation metrics commonly available through Google Scholar. We captured total citations, h-indices (which Hamermesh (2018) characterizes as combining both the breadth and depth of impact) and i10indices (which measure the number of papers with at least 10 citations) for each individual with a Google Scholar profile. ${ }^{6}$ Unfortunately, there are a number of faculty members who do not have a Google profile or have not made their profiles public. For these faculty members, we used multiple imputation to fill in the missing citation data for some of our analyses and excluded the records

\footnotetext{
${ }^{5}$ Nearly all of the individuals excluded on these grounds were employed by schools of public affairs and held juris doctorates.

${ }^{6}$ The h-index is calculated by counting the number of publications for which a scholar has been cited by other scholars at least that same number of times. For example, a h-index of 16 means that the scholar has published at least 16 papers that have each been cited at least 16 times. The i10-index is the number of publications with at least 10 citations. For example, an i10-index of 12 means that 12 publications of the scholar have each been cited at least 10 times.
} 
with missing data for other estimates of the same specifications. None of our results were substantively changed by the modeling choices regarding missing data.

Table 2 provides summary statistics on the distribution of faculty by departmental affiliation, sex, and annual salary compensation. As these sample summary statistics make clear, we were able to confirm each of our motivating observations. First, leading schools of public affairs employ a large number of economists. The 33 leading public affairs departments in our sample employed more than 100 economists, or 12 percent of the economists in the sample.

Second, a disproportionate number of the economists employed by schools of public affairs were female. As Table 2 illustrates, 19 percent of the faculty in departments of economics were female; whereas 23 percent of the economists in departments of political science were female and 35 percent of the economists in schools of public affairs were female. In other words, the fraction female among economists in schools of public affairs was nearly double the fraction female in traditional departments of economics. This difference among economists between departments of economics and public affairs was statistically significant by any common metric.

Third, average salaries in schools of public affairs were lower than those in traditional economics departments. On average - and without adjustment for faculty rank or institution reporting differences - salaries were 33.5 percent higher in departments of economics than they were in schools of public affairs. Among economists, average salaries were 11 percent higher in departments of economics than they were in schools of public affairs.

[Table 2 about here]

\section{EMPIRICAL ANALYSIS AND DISCUSSION OF RESULTS}

Of course, average salaries are not the best comparisons. Therefore, consider the hedonic salary models reported in Table 3. In general, we estimated the following functional form, 


$$
\ln \left(\text { Salary }_{i d}\right)=\alpha+\text { Faculty }_{i d} \cdot \beta+X_{i d} \cdot \delta+\tau_{j}+\mu_{i d}
$$

where $\ln \left(\right.$ Salary $\left._{i d}\right)$ is the $\log$ of annual salary for faculty member $i$ in department $d$, Faculty id $_{\text {id }}$ a vector of faculty characteristics, such as, departmental affiliation (school of public affairs (omitted category), economics department, and political science department), field of specialization (economist, political scientist, and other fields (omitted category)), female indicator, professor rank indicator (assistant professor (omitted category), associate professor, and full professor), and experience level of the faculty as measured by the log of years since their Ph.D. degree; $X_{i d}$ is a vector of variables capturing various measures of faculty productivity, such as, total citation count, h-index, and i10-index; $\tau_{j}$ are university fixed effects; and lastly, $\mu_{i d}$ is the error term.

The first column in Table 3 shows a parsimonious model specification with university fixed effects (which allowed us to control for systematic, unobservable differences by institution such as differences in fringe benefits, salary reporting protocols or reporting years) and indicators for departmental affiliation and discipline, but no other controls. This model indicated that the average salary for economists in economics departments was 17 percent (the exponent of the coefficient of $0.154=1.17$ ) higher than the average salary for economists at the same institution who were not in economics departments, and 32 percent (the exponent of $0.154+0.124=1.32$ ) higher than the average salary for faculty members in schools of public affairs who were neither economists nor political scientists (the omitted category). Thus, our first cut at the data suggested that economists in schools of public affairs were paid at a significant discount vis-'a-vis those in traditional departments of economics.

[Table 3 about here] 
This pattern led us to hypothesize that salaries were lower in schools of public affairs because the faculty members who chose to work in such contexts were systematically different from those who chose to work in traditional departments of economics. Those differences could have existed upon arrival (such as gender) or could have been influenced by context (such as scholarly productivity).

\section{Alternative Explanation \#1: Faculty Sorting by Gender}

It is clear from Table 2 that there is departmental sorting by gender. Moreover, it is welldocumented that the economics profession has had, and continues to have, problems with gender equity. ${ }^{7}$ So, the apparent public affairs discount could simply reflect the greater share of female faculty in schools of public affairs. To explore this hypothesis, the second column in Table 3 presents a model that included an indicator for female faculty member. As the table makes clear, we found a significant, negative differential for female faculty members, but controlling for gender did not eliminate the public affairs discount.

Next, we considered a model that included not only an indicator for female faculty, but also the interactions between gender and discipline (to allow for the possibility that there are gender-linked salary differentials among economists, but not among political scientists or among other public affairs disciplines) and the interactions between gender and department affiliation (to allow for the possibility that bias is more strongly expressed in traditional economics departments than in schools of public affairs). As column (3) of Table 3 illustrates, this model suggested that female faculty members were paid significantly less than male faculty members regardless of discipline or department. All of the gender interaction terms were jointly insignificant $(\mathrm{F}(4,2110)$ $=1.34, \mathrm{p}=0.25)$. Again, controlling for gender did not eliminate the public affairs discount.

\footnotetext{
${ }^{7}$ See, for example the discussion in Lundberg and Stearns (2019) and Ceci et al. (2014). See also Wu (2018).
} 


\section{Alternative Explanation \#2: Faculty Sorting by Experience and Rank}

Maybe there were systematic differences between male and female faculty members or between departments of economics and schools of public affairs with respect to faculty rank and experience. The fourth and fifth columns in Table 3 present models that included faculty rank and years since degree (in logs), and the interactions between these two measures of productivity and the economist and political scientist indictors (to allow the effects of rank and experience to vary by discipline). ${ }^{8}$ Because some of the records do not have year of degree, we report both a model in which we dropped observations with missing data on experience (shown in column (4)) and a model in which we multiply imputed years since degree using 100 imputations (shown in column (5)). For observations for which years since degree was imputed, each interaction term was treated as just another variable, meaning that the data were transformed and then the interactions were imputed, as recommended in Von Hippel (2009) and Seaman, Bartlett, and White (2012).

As Table 3 illustrates, the results shown in columns (4) and (5) were not sensitive to the imputation. In both models, we found that controlling for years of experience and faculty rank greatly reduced the magnitude of the difference between male and female salaries, but the gender difference remained large and statistically significant. Again, all of the sex interaction terms were jointly insignificant $(F(4,1930)=0.51, p=0.73$ in column $(4) ; F(4,2099)=0.74, p=0.57$ in column (5)) suggesting that the systematic difference between male and female salaries was not a function of discipline or departmental affiliation. Furthermore, this modeling change was associated with a modest increase in the economics department premium, so there was no evidence that the public affairs discount arose from sorting by sex or seniority.

\footnotetext{
${ }^{8}$ Although some argue that faculty rank is endogenous, excluding rank as a control can produce misleading conclusions, particularly in the case of gender equity, showing bias where none exists and vice versa (Boudreau et al., 1997).
} 


\section{Alternative Explanation \#3: Faculty Sorting by Other Indicators of Research Productivity}

Experience and professorial rank are highly imperfect measures of scholarly productivity. Suspecting that there were other dimensions of research productivity that could help explain the gender differential and the public affairs discount, we turned our attention to the faculty citation metrics available from Google Scholar-citation counts, h-indices and i10-indices.

We note that many researchers do not make their Google Scholar profiles public. Therefore, we were unable to collect citation metrics for more than one third of the researchers in our analysis sample. Again, we relied on multiple imputation to fill in the blanks.

Furthermore, we could not conclude that the citation metrics were missing completely at random. As shown in panel A of Table 4, multinomial probit models indicate that the probability that faculty members lacked a public Google Scholar profiles was an increasing function of the number of years since their doctoral degrees. We found this pattern whether or not the model included imputed values for years since degree. In addition, full professors appeared somewhat more likely to have a public Google Scholar profile than assistant or associate professors, once we controlled for differences in graduation date. Therefore, it was necessary to control for faculty rank and years since degree in the imputation model for each of the Google Scholar metrics.

The remaining panels of Table 4 provide reasons to believe that variations in the citation metrics could at least partially explain the observed differences in salary by sex and departmental affiliation. Although the variables were seldom individually significant, the hypothesis that the female indicator and all its interactions were jointly zero was rejected at the 5-percent level for each of the citation metrics. The hypothesis that the economics department indicator and the interaction between female and the economics department indicator were jointly zero was rejected at the five percent level for both the h-index and i10-index models, but not the citation count model, 
suggesting that departmental affiliation matters for at least some of the citation metrics. Intriguingly, where departmental affiliation is statistically significant (i.e., in the h-index and i10index models), the evidence suggests that scholarly productivity among male economists is lower in traditional departments of economics than in schools of public affairs, all other things being equal, while scholarly productivity among female economists is unrelated to departmental affiliation. On the other hand, the h-indices and i10-indices were systematically lower for female economists than for male economists in both traditional economics departments and schools of public affairs, although the differential was smaller and only significant at the 10-percent level in traditional departments of economics.

[Table 4 about here]

Next, Table 5 presents variations on column (5) of Table 3, which we added the citation metrics and appropriate interaction terms. The interactions between gender and departmental affiliation, which were uniformly negligible in preliminary analyses, have been dropped to avoid over-parameterization.

In the first column, we present a model that omitted observations without citation data. In all other specifications, the citation-based indicators of productivity were multiply imputed to address the problem of missing data. Because whether or not the Google Scholar data were missing depended on the years since degree, it was necessary to use years since degree to impute the citation metrics. As a result, all of these models exclude observations for which years since degree was missing.

As the table illustrates, we found a significant, positive and multi-collinear relationship between the citation metrics and faculty salaries. As shown in column (4), each additional oneunit increase in the h-index was associated with a one percent increase in faculty salary, all other 
things being equal. Increases in citation count had no incremental effect on salary, once the hindex and i10-index were taken into account, and increases in the i10-index were slightly negative, holding the other citation metric constant (shown column (2)). However, when each of the metrics was evaluated separately, there was consistent evidence that increases in citation led to increases in salary (columns (3)-(5)).

[Table 5 about here]

Incorporating citation metrics into the analysis altered the estimated relationship between gender and salary. The marginal effect of gender shrank, and in the imputed specifications became statistically insignificant. In none of the specifications was the marginal effect of being a female economist statistically significant at the 5-percent level (although it was significant at the 5-percent level in the model where citation counts were not imputed, and therefore fewer highly experienced scholars were included).

Interestingly, the public affairs discount widened. As column (2) shows, controlling for citation metrics as well as years since degree and faculty rank, we estimated that economists in schools of public affairs earned at least 28 percent more than otherwise similar faculty members, and economists in departments of economics earned 17 percent more than economists in schools of public affairs. On the other hand, political scientists were better paid in a school of public affairs than in a traditional department of political science, even after controlling for research productivity. As Table 5 illustrates, political scientists in mainline political science departments were paid 10 percent less, on average, than political scientists in schools of public affairs.

We wondered if perhaps the public affairs discount arose from systematic differences in the relative prestige of the various departments. After all, our sample was restricted to public universities that are home to leading schools of public affairs - which does not necessarily imply 
that they are also home to leading departments of economics or political science. One could argue that the premium for political scientists in leading schools of public affairs could arise from differences in departmental prestige (as in Ehrenberg, McGraw, and Mrdjenovic, 2006) although it would seem difficult to make such a case for the public affairs discount vis-à-vis a less selective set of departments of economics.

Nevertheless, we explored this possibility as well, by adding two interaction terms to the model. The first is the interaction between the economics department indicator and the US News and World Report rankings for the university's department of economics; the second is the interaction between the political science department indicator and the US News and World Report ranking for the university's department of political science. (We do not add the main effects of the departmental rankings because those are subsumed in the university fixed effects.) As the last column in Table 5 makes clear, controlling for the departmental rankings added nothing to the analysis.

We wondered if the results regarding the vanishing gender differential and persistent public affairs discount could be driven by the salary or reporting practices at an outlier university. Therefore, we performed a jackknife-inspired sensitivity analysis of our preferred specification (column (2)), by excluding one university at a time from the data file, re-imputing, and reestimating. In all cases, there was no systematic gender differential once citations were taken into account, and the sign, significance and magnitude of the departmental premiums were largely unaffected. (Tables available upon request.)

[Table 6 about here]

Lastly, we also wondered if the return to citations might be higher among economists than among the other social scientists typically found in schools of public affairs. We found mixed 
evidence on that front. As Table 6 illustrates, when we allowed for an interaction between gender or discipline and the citation metrics, we found no evidence that the marginal effect was higher for economists than for political scientists, but some evidence (from the non-imputed models) that the marginal effect of an increase in citations was larger for these two social science disciplines than for other disciplines found in schools of public affairs. Contrary to the findings of Sarsons (2017) we found no reason to believe that the return to citations was systematically different for males than for female faculty members in the institutions of higher education under analysis.

\section{CONCLUDING REMARKS}

Our salary study provides insight into fiscal practices at highly-ranked public universities around the United States. In agreement with the literature reviewed, we found evidence of lower average wages for women, as well as all faculty in departments that include a higher proportion of women. The female differential disappeared when we controlled for citation record, but the disciplinary and departmental differentials did not. We found some evidence that citation records differed by gender, which is consistent with previous work by Dion, Sumner, and Mitchell (2018) and Ferber and Brün (2011) suggesting that citation practices disadvantage female faculty members. We also found evidence that economists had fewer citations, yet substantially higher wages than their colleagues from other disciplines.

Interestingly, our analysis did reveal a persistent pattern: economists in schools of public affairs were paid at a significant discount, while their political scientists' colleagues were paid at a significant premium, relative to their counterparts in disciplinary departments. In other words, salaries across disciplines within schools of public affairs were more homogeneous than were the 
salaries across disciplines between disciplinary departments in the same universities. Furthermore, this pattern could not be explained by faculty sorting on gender.

Two competing hypotheses could explain the schools of public affairs salary discount for economists (and salary premium for political scientists). First, schools of public affairs could have been trying to sustain some outdated, internal equity standard in the face of rising relative salaries for economists (Curtis and Kisielewski, 2015). Buchanan and Tollison (1982) refer to this practice as the homogenization of heterogeneous inputs.

Second, both economist and political scientists who are employed at schools of public affairs are fairly quantitative in nature - that is, their scholarly work is inherently applied and some type of statistical modeling is common in their research. It is possible that the apparent public affairs discount is really just a manifestation of an applied micro or public finance discount. This would imply that there is an "applied discount" for economists who work at schools of public affairs, while their political scientists enjoy an "applied premium."

Regardless of which competing hypothesis might be true, one thing is for certain, economists who chose public affairs departments experienced an estimated 18 percent salary loss relative to their peers in departments of economics. Card, Mas, Moretti, and Saez (2012) argued that relative perceptions of salary reduce job satisfaction for individuals earning below the median, with individuals also reporting a higher likelihood of seeking employment elsewhere. In order to facilitate intra-departmental cordiality, administrators may consider paying the economists on their faculty a wage that more accurately reflects the relative pay of their peers in economics departments. 


\section{References}

Barbezat, Debra A. (2004). A loyalty tax? National measures of academic salary compression. Research in Higher Education, 45(7), pp. 761-776.

Bellas, Marcia L. (1994). Comparable worth in academia: The effects on faculty salaries of the sex composition and labor-market conditions of academic disciplines. American Sociological Review, 59(6), pp. 807-821.

Bellas, Marcia L. (1997). Disciplinary differences in faculty salaries: Does gender bias play a role? The Journal of Higher Education, 68(3), pp. 299-321.

Binder, M., K. Krause, J. Chermak, J. Thacher, and J. Gilroy. (2010). Same work, different pay? Evidence from a US public university. Feminist Economics, 16(4), pp. 105-135.

Blau, F. D., and L. M. Kahn. (2017). The gender wage gap: Extent, trends, and explanations. Journal of Economic Literature, 55(3), pp. 789-865.

Boudreau, Nancy, James Sullivan, William Balzer, Ann Marie Ryan, Robert Yonker, Todd Thorsteinson, and Peter Hutchinson. (1997). Should faculty rank be included as a predictor variable in studies of gender equity in university faculty salaries? Research in Higher Education, 38(3), pp. 297-312.

Boyle, G. (2008). Pay peanuts and get monkeys? Evidence from academia. The BE Journal of Economic Analysis \& Policy, 8(1), ISSN (Online) 1935-1682.

Buchanan, James M., and Robert D. Tollison. (1981). The homogenization of heterogeneous inputs. American Economic Review, 71(1), pp. 28-38.

Card, David, Alexandre Mas, Enrico Moretti, and Emmanuel Saez. (2012). Inequality at work: The effect of peer salaries on job satisfaction. American Economic Review, 102(6), pp. 2981-3003.

Carlin, P. S., M. P. Kidd, P. M. Rooney, and B. Denton. (2013). Academic wage structure by gender: The roles of peer review, performance, and market forces. Southern Economic Journal, 80(1), pp. 127-146.

Ceci, S. J., D. K. Ginther, S. Kahn, and W. M. Williams. (2014). Women in academic science: A changing landscape. Psychological Science in the Public Interest, 15(3), pp. 75-141.

Claypool, Vicki Hesli, Brian David Janssen, Dongkyu Kim, and Sara McLaughlin Mitchell. (2017). Determinants of salary dispersion among political science faculty: The differential effects of where you work (institutional characteristics) and what you do (negotiate and publish). PS: Political Science \& Politics, 50(1), pp. 146-156.

Curtis, John, and Michael Kisielewski. (2015). The Need to Know: Faculty Salaries in Sociology and Other Disciplines. Washington: American Sociological Association.

Diamond Jr., Arthur M. (1986). What is a citation worth? The Journal of Human Resources, 21(2), pp. 200-215.

Dion, Michelle L, Jane Lawrence Sumner, and Sara McLaughlin Mitchell. (2018). Gendered citation patterns across political science and social science methodology fields. Political Analysis, 26(3), pp. 312-327.

Ehrenberg, Ronald G. (2004a). Don't blame faculty for high tuition: The annual report on the economic status of the profession 2003-04. Academe, 90(2), pp. 19-103.

Ehrenberg, Ronald G. (2004b). Prospects in the academic labor market for economists. Journal of Economic Perspectives, 18(2), pp. 227-238. 
Ehrenberg, Ronald G., Marquise McGraw, and Jesenka Mrdjenovic. (2006). Why do field differentials in average faculty salaries vary across universities? Economics of Education Review, 25(3), pp. 241-248.

Fairweather, James S. (1995). Myths and realities of academic labor markets. Economics of Education Review, 14(2), pp. 179-192.

Ferber, Marianne A, and Michael Brün. (2011). The gender gap in citations: does it persist? Feminist Economics, 17(1), pp. 151-158.

Fourcade, Marion, Etienne Ollion, and Yann Algan. (2015). The superiority of economists. Journal of Economic Perspectives, 29(1), pp. 89-114.

Freeman, Richard B. (1999). It's better being an economist (but don't tell anyone). Journal of Economic Perspectives, 13(3), pp.139-145.

Friedman, Lee S. (1991). Economists and public policy programs. Journal of Policy Analysis and Management, 10(2), pp. 343-359.

Gibson, J., D. L. Anderson, and J. Tressler. (2017). Citations or journal quality: Which is rewarded more in the academic labor market? Economic Inquiry, 55(4), pp. 1945-1965.

Gibson, J., and E. Burton-McKenzie. (2017). Are returns to research quality lower in agricultural economics than in economics? Australian Journal of Agricultural and Resource Economics, 61(3), pp. 498-514.

Ginther, Donna K. (2003). Is MIT an exception? Gender pay differences in academic science. Bulletin of Science Technology \& Society, 23, pp. 21-26.

Ginther, Donna K., and K. J. Hayes. (2003). Gender differences in salary and promotion for faculty in the humanities 1977-1995. The Journal of Human Resources, 38(1), pp. 34-73.

Ginther, Donna K., and Shulamit Kahn. (2004). Women in economics: moving up or falling off the academic career ladder? Journal of Economic perspectives, 18(3), pp. 193-214.

Gomez-Mejia, Luis R, and David B. Balkin. (1992). Determinants of faculty pay: An agency theory perspective. Academy of Management Journal, 35(5), pp. 921-955.

Hamermesh, D. S. (2018). Citations in Economics: Measurement, Uses, and Impacts. Journal of Economic Literature, 56(1), pp. 115-156.

Hamermesh, D. S., G. E. Johnson, and B. A. Weisbrod. (1982). Scholarship, citations and salaries: Economic rewards in economics. Southern Economic Journal, 49(2), pp. 472-481.

Hilmer, C. E., M. J. Hilmer, and J. L. Lusk. (2012). A comparison of salary structures between economics and agricultural economics departments. Applied Economic Perspectives and Policy, 34(3), pp. 489-514.

Langton, Nancy, and Jeffrey Pfeffer. (1994). Paying the professor: Sources of salary variation in academic labor markets. American Sociological Review, 59(2), pp. 236-256.

Lundberg, S., and J. Stearns. (2019). Women in economics: Stalled progress. Journal of Economic Perspectives, 33(1), pp. 3-22.

Masakure, O. (2016). The effect of employee loyalty on wages. Journal of Economic Psychology, 56, pp. 274-298.

Park, Toby. (2012). Do faculty members get what they deserve?: A review of the literature surrounding the determinants of salary, promotion and tenure. Journal of the Professoriate, 6(1), pp. 28-47.

Perna, Laura W. (2003). Studying faculty salary equity: A review of theoretical and methodological approaches. In Higher education: Handbook of theory and research, pp. 323-388. Springer. 
Renzulli, L. A., J. Reynolds, K. Kelly, and L. Grant. (2013). Pathways to gender inequality in faculty pay: the impact of institution, academic division, and rank. Research in Social Stratification and Mobility, 34, pp. 58-72.

Sarsons, H. (2017). Recognition for group work: Gender differences in academia. American Economic Review, 107(5), pp. 141-145.

Seaman, S. R., J. W. Bartlett, and I. R. White. (2012). Multiple imputation of missing covariates with non-linear effects and interactions: an evaluation of statistical methods. BMC Medical Research Methodology, 12(1), pp. 46.

Smart, John C. (1991). Gender equity in academic rank and salary. The Review of Higher Education, 14(4), pp. 511-525.

Tuckman, B. H., and H. P. Tuckman. (1976). The structure of salaries at American universities. The Journal of Higher Education, 47(1), pp. 51-64.

Umbach, Paul D. (2007). Gender equity in the academic labor market: An analysis of academic disciplines. Research in Higher Education, 48(2), pp. 169-192.

Volk, Cindy S, Sheila Slaughter, and Scott L. Thomas. (2001). Models of institutional resource allocation: Mission, market, and gender. The Journal of Higher Education, 72(4), pp. 387413.

Von Hippel, P. T. (2009). How to impute interactions, squares, and other transformed variables. Sociological Methodology, 39(1), pp. 265-291.

Webber, K. L., and M. González Canché. (2015). Not equal for all: Gender and race differences in salary for doctoral degree recipients. Research in Higher Education, 56(7), pp. 645-672.

$\mathrm{Wu}$, Alice H. (2018). Gendered Language on the Economics Job Market Rumors Forum. American Economic Review Papers and Proceedings, 108, pp. 175-179. 
Table 1: Sample Descriptive Statistics

\begin{tabular}{|c|c|c|c|c|}
\hline & No. Observations & Mean & Minimum & Maximum \\
\hline Salary $(\log )$ & 2,152 & $\begin{array}{l}11.81 \\
(0.42)\end{array}$ & 10.60 & 13.14 \\
\hline School of Public Affairs & 2,152 & 0.32 & 0 & 1 \\
\hline Economics Department & 2,152 & 0.34 & 0 & 1 \\
\hline Political Science Department & 2,152 & 0.34 & 0 & 1 \\
\hline Economist & 2,152 & 0.39 & 0 & 1 \\
\hline Political Scientist & 2,152 & 0.40 & 0 & 1 \\
\hline Other Fields & 2,152 & 0.21 & 0 & 1 \\
\hline Female Faculty & 2,152 & 0.30 & 0 & 1 \\
\hline Male Faculty & 2,152 & 0.70 & 0 & 1 \\
\hline Assistant Professor & 2,152 & 0.26 & 0 & 1 \\
\hline Associate Professor & 2,152 & 0.31 & 0 & 1 \\
\hline Full Professor & 2,152 & 0.43 & 0 & 1 \\
\hline Year of Ph.D. Degree & 1,981 & $\begin{array}{c}1998.79 \\
(12.84)\end{array}$ & 1957 & 2017 \\
\hline Google Scholar's Total Citation Count & 1,337 & $\begin{array}{c}2992.02 \\
(6331.08)\end{array}$ & 1 & 100367 \\
\hline Google Scholar's h-index & 1,337 & $\begin{array}{c}17.20 \\
(13.52)\end{array}$ & 1 & 102 \\
\hline Google Scholar's i10-index & 1,337 & $\begin{array}{c}26.12 \\
(31.72)\end{array}$ & 0 & 281 \\
\hline
\end{tabular}

Notes: Standard deviations are in parentheses for continuous variables. The variable "Other Fields" include other fields whose faculty members are in the school of public affairs, such as, sociology, demography, anthropology, etc. Productivity measures (i.e., total citation count, h-index, and i10-index) were obtained from each faculty's Google Scholar profiles. See Appendix 1 for detailed description of variables listed in Table 1.

Source: Authors' calculations. 
Table 2: The Distribution of Faculty by Departmental Affiliation, Gender, and Annual Salary Compensation

\begin{tabular}{|c|c|c|c|c|c|c|}
\hline \multirow[b]{2}{*}{ Departmental Affiliation } & \multicolumn{4}{|c|}{ Panel A: Faculty by Department and Gender } & \multicolumn{2}{|c|}{ Panel B: Compensation (\$000's) } \\
\hline & $\begin{array}{l}\text { No. of Faculty } \\
\text { Members }\end{array}$ & $\begin{array}{l}\text { Percent } \\
\text { Female }\end{array}$ & $\begin{array}{c}\text { No. of } \\
\text { Economists }\end{array}$ & $\begin{array}{l}\text { Percent } \\
\text { Female }\end{array}$ & Average Salary & $\begin{array}{c}\text { Average } \\
\text { Economist Salary }\end{array}$ \\
\hline School Public Affairs & 701 & $40.7 \%$ & 102 & $35.3 \%$ & $\$ 134$ & $\$ 161$ \\
\hline Economics & 685 & $18.7 \%$ & 685 & $18.7 \%$ & $\$ 179$ & $\$ 179$ \\
\hline Political Science & 666 & $31.1 \%$ & 13 & $23.1 \%$ & $\$ 126$ & $\$ 183$ \\
\hline Joint Appointments & 100 & $27.0 \%$ & 46 & $21.7 \%$ & $\$ 168$ & $\$ 199$ \\
\hline Total & 2,152 & $30.1 \%$ & 846 & $20.9 \%$ & $\$ 147$ & $\$ 178$ \\
\hline
\end{tabular}

Notes: Annual salary compensation are in current dollars, circa 2017.

Source: Authors' calculations. 
Table 3: Ordinary Least Squares (OLS) Regression Results - Hedonic Wage Models

\begin{tabular}{|c|c|c|c|c|c|}
\hline & (1) & (2) & (3) & (4) & $(5)$ \\
\hline Economics Department & $\begin{array}{c}0.154 * * * \\
(0.033)\end{array}$ & $\begin{array}{l}0.133 * * * \\
(0.0329)\end{array}$ & $\begin{array}{c}0.117 * * * \\
(0.041)\end{array}$ & $\begin{array}{c}0.154 * * * \\
(0.034)\end{array}$ & $\begin{array}{c}0.147 * * * \\
(0.033)\end{array}$ \\
\hline Political Science Department & $\begin{array}{c}-0.119 * * * \\
(0.035)\end{array}$ & $\begin{array}{c}-0.126 * * * \\
(0.0353)\end{array}$ & $\begin{array}{c}-0.0896^{* *} \\
(0.045)\end{array}$ & $\begin{array}{c}-0.0875 * * * \\
(0.033)\end{array}$ & $\begin{array}{c}-0.0956^{* * * *} \\
(0.031)\end{array}$ \\
\hline Economist & $\begin{array}{c}0.124 * * * \\
(0.033)\end{array}$ & $\begin{array}{l}0.119 * * * \\
(0.0326)\end{array}$ & $\begin{array}{c}0.123 * * * \\
(0.041)\end{array}$ & $\begin{array}{c}0.243 * * * \\
(0.071)\end{array}$ & $\begin{array}{c}0.247 * * * \\
(0.070)\end{array}$ \\
\hline Political Scientist & $\begin{array}{l}0.0257 \\
(0.035)\end{array}$ & $\begin{array}{c}0.0208 \\
(0.0353)\end{array}$ & $\begin{array}{c}-0.00707 \\
(0.046)\end{array}$ & $\begin{array}{l}-0.0714 \\
(0.071)\end{array}$ & $\begin{array}{l}-0.0728 \\
(0.070)\end{array}$ \\
\hline Female Faculty & & $\begin{array}{c}-0.117 * * * \\
(0.0159)\end{array}$ & $\begin{array}{c}-0.124 * * * \\
(0.030)\end{array}$ & $\begin{array}{c}-0.0534 * * \\
(0.027)\end{array}$ & $\begin{array}{c}-0.0636^{* *} \\
(0.025)\end{array}$ \\
\hline Female Faculty x Economist & & & $\begin{array}{l}-0.016 \\
(0.064)\end{array}$ & $\begin{array}{l}0.0201 \\
(0.058)\end{array}$ & $\begin{array}{l}0.0221 \\
(0.056)\end{array}$ \\
\hline Female Faculty x Political Scientist & & & $\begin{array}{l}0.0737 \\
(0.069)\end{array}$ & $\begin{array}{l}0.0618 \\
(0.055)\end{array}$ & $\begin{array}{l}0.0784 \\
(0.052)\end{array}$ \\
\hline Female Faculty x Economics Department & & & $\begin{array}{l}0.0675 \\
(0.068)\end{array}$ & $\begin{array}{l}0.0029 \\
(0.059)\end{array}$ & $\begin{array}{l}0.0152 \\
(0.057)\end{array}$ \\
\hline Female Faculty x Political Science Department & & & $\begin{array}{l}-0.103 \\
(0.067)\end{array}$ & $\begin{array}{l}-0.0662 \\
(0.052)\end{array}$ & $\begin{array}{l}-0.0666 \\
(0.051)\end{array}$ \\
\hline Years Since PhD Degree (log) & & & & $\begin{array}{c}0.00377 \\
(0.027)\end{array}$ & $\begin{array}{c}0.00484 \\
(0.027)\end{array}$ \\
\hline Years Since PhD Degree (log) x Economist & & & & $\begin{array}{c}-0.0748 * * \\
(0.033)\end{array}$ & $\begin{array}{c}-0.0764 * * \\
(0.034)\end{array}$ \\
\hline Years Since PhD Degree (log) x Political Scientist & & & & $\begin{array}{l}0.0402 \\
(0.034)\end{array}$ & $\begin{array}{l}0.0399 \\
(0.034)\end{array}$ \\
\hline Associate Professor & & & & $\begin{array}{c}0.267 * * * \\
(0.042)\end{array}$ & $\begin{array}{c}0.265 * * * \\
(0.041)\end{array}$ \\
\hline Associate Professor $\mathrm{x}$ Economist & & & & $\begin{array}{c}0.00967 \\
(0.054)\end{array}$ & $\begin{array}{c}0.00927 \\
(0.052)\end{array}$ \\
\hline Associate Professor x Political Scientist & & & & $\begin{array}{c}-0.124^{* *} \\
(0.053)\end{array}$ & $\begin{array}{c}-0.123 * * \\
(0.051)\end{array}$ \\
\hline Full Professor & & & & $\begin{array}{c}0.557 * * * \\
(0.057)\end{array}$ & $\begin{array}{c}0.528 * * * \\
(0.056)\end{array}$ \\
\hline Full Professor $\mathrm{x}$ Economist & & & & $\begin{array}{l}0.0963 \\
(0.069)\end{array}$ & $\begin{array}{l}0.118 * \\
(0.068)\end{array}$ \\
\hline Full Professor x Political Scientist & & & & $\begin{array}{l}-0.0647 \\
(0.069)\end{array}$ & $\begin{array}{l}-0.0457 \\
(0.068)\end{array}$ \\
\hline Constant & $\begin{array}{c}11.74 * * * \\
(0.016)\end{array}$ & $\begin{array}{l}11.79 * * * \\
(0.0169)\end{array}$ & $\begin{array}{c}11.79 * * * \\
(0.020)\end{array}$ & $\begin{array}{l}11.45^{* * *} \\
(0.053)\end{array}$ & $\begin{array}{c}11.46^{* * * *} \\
(0.053)\end{array}$ \\
\hline University Fixed Effects & Yes & Yes & Yes & Yes & Yes \\
\hline Imputated Data & No & No & No & No & Yes \\
\hline Number of Imputated Interations & -- & -- & -- & -- & 100 \\
\hline No. Observations & 2,152 & 2,152 & 2,152 & 1,981 & 2,152 \\
\hline Adjusted $\mathrm{R}^{2}$ & 0.34 & 0.35 & 0.36 & 0.63 & -- \\
\hline
\end{tabular}

Notes: Standard errors (shown in parentheses). The ommitted comparison category for professor's rank is Assistant Professor. For column (5), the variables "Years Since PhD Degree (log)" and corresponding interaction terms were imputed with 100 iterations. See Appendix 1 for detailed description of variables listed in Table 3.*****,* denotes statistical significant at the 1 percent, 5 percent, 10 percent levels, respectively. 
Table 4: Imputing Google Scholar Profile Citation Metrics

\begin{tabular}{|c|c|c|c|c|c|c|c|c|}
\hline & \multicolumn{2}{|c|}{$\begin{array}{l}\text { Panel A: Logit Models } \\
\text { Probability of a Missing } \\
\text { Google Scholar Profile }\end{array}$} & \multicolumn{2}{|c|}{$\begin{array}{l}\text { Panel B: OLS Models } \\
\text { Log Citation Count }\end{array}$} & \multicolumn{2}{|c|}{$\begin{array}{c}\text { Panel C: OLS Models } \\
\text { h-index }\end{array}$} & \multicolumn{2}{|c|}{$\begin{array}{c}\text { Panel D: OLS Models } \\
\text { i10-index }\end{array}$} \\
\hline & (1) & (2) & (1) & (2) & (1) & (2) & (1) & (2) \\
\hline Economics Department & $\begin{array}{c}0.181 \\
(0.178)\end{array}$ & $\begin{array}{c}0.123 \\
(0.170)\end{array}$ & $\begin{array}{l}-0.063 \\
(0.141)\end{array}$ & $\begin{array}{l}-0.060 \\
(0.140)\end{array}$ & $\begin{array}{c}-4.043^{* * * *} \\
(1.372)\end{array}$ & $\begin{array}{c}-3.930 * * * \\
(1.333)\end{array}$ & $\begin{array}{c}-18.19^{* * *} \\
(3.605)\end{array}$ & $\begin{array}{c}-17.90^{* * *} \\
(3.502)\end{array}$ \\
\hline Political Science Department & $\begin{array}{l}-0.124 \\
(0.166)\end{array}$ & $\begin{array}{l}-0.094 \\
(0.158)\end{array}$ & $\begin{array}{c}0.031 \\
(0.155)\end{array}$ & $\begin{array}{c}0.035 \\
(0.150)\end{array}$ & $\begin{array}{l}-0.997 \\
(1.505)\end{array}$ & $\begin{array}{l}-0.648 \\
(1.431)\end{array}$ & $\begin{array}{l}-3.095 \\
(3.954)\end{array}$ & $\begin{array}{c}-2.15 \\
(3.758)\end{array}$ \\
\hline Economist & $\begin{array}{c}0.240 \\
(0.373)\end{array}$ & $\begin{array}{c}0.202 \\
(0.364)\end{array}$ & $\begin{array}{c}-0.691 * * \\
(0.333)\end{array}$ & $\begin{array}{c}-0.735^{* *} \\
(0.334)\end{array}$ & $\begin{array}{l}-6.250^{*} \\
(3.232)\end{array}$ & $\begin{array}{c}-6.431^{* *} \\
(3.145)\end{array}$ & $\begin{array}{l}-9.079 \\
(8.491)\end{array}$ & $\begin{array}{l}-9.591 \\
(8.270)\end{array}$ \\
\hline Political Scientist & $\begin{array}{c}0.156 \\
(0.372)\end{array}$ & $\begin{array}{c}0.033 \\
(0.364)\end{array}$ & $\begin{array}{l}-0.213 \\
(0.337)\end{array}$ & $\begin{array}{l}-0.265 \\
(0.338)\end{array}$ & $\begin{array}{l}-4.319 \\
(3.275)\end{array}$ & $\begin{array}{l}-4.691 \\
(3.178)\end{array}$ & $\begin{array}{l}-9.491 \\
(8.604)\end{array}$ & $\begin{array}{l}-10.59 \\
(8.338)\end{array}$ \\
\hline Female Faculty & $\begin{array}{c}0.037 \\
(0.140)\end{array}$ & $\begin{array}{c}0.066 \\
(0.126)\end{array}$ & $\begin{array}{l}-0.170 \\
(0.121)\end{array}$ & $\begin{array}{l}-0.132 \\
(0.114)\end{array}$ & $\begin{array}{l}-1.142 \\
(1.172)\end{array}$ & $\begin{array}{l}-0.856 \\
(1.089)\end{array}$ & $\begin{array}{c}-4.13 \\
(3.079)\end{array}$ & $\begin{array}{l}-3.704 \\
(2.859)\end{array}$ \\
\hline Female Faculty $\mathrm{x}$ Economist & $\begin{array}{c}0.202 \\
(0.303)\end{array}$ & $\begin{array}{c}0.139 \\
(0.289)\end{array}$ & $\begin{array}{l}0.105 \\
(0.255)\end{array}$ & $\begin{array}{c}0.078 \\
(0.250)\end{array}$ & $\begin{array}{l}-4.631^{*} \\
(2.476)\end{array}$ & $\begin{array}{l}-4.619^{*} \\
(2.382)\end{array}$ & $\begin{array}{c}-18.79 * * * \\
(6.504)\end{array}$ & $\begin{array}{c}-18.55^{* * *} \\
(6.255)\end{array}$ \\
\hline Female Faculty x Political Scientist & $\begin{array}{l}-0.182 \\
(0.278)\end{array}$ & $\begin{array}{l}-0.082 \\
(0.262)\end{array}$ & $\begin{array}{c}0.255 \\
(0.252)\end{array}$ & $\begin{array}{c}0.226 \\
(0.246)\end{array}$ & $\begin{array}{c}0.141 \\
(2.448)\end{array}$ & $\begin{array}{c}0.136 \\
(2.346)\end{array}$ & $\begin{array}{c}0.408 \\
(6.430)\end{array}$ & $\begin{array}{c}0.784 \\
(6.160)\end{array}$ \\
\hline Female Faculty x Economics Department & $\begin{array}{c}0.075 \\
(0.306)\end{array}$ & $\begin{array}{c}0.092 \\
(0.295)\end{array}$ & $\begin{array}{c}0.022 \\
(0.258)\end{array}$ & $\begin{array}{c}0.020 \\
(0.254)\end{array}$ & $\begin{array}{c}3.734 \\
(2.500)\end{array}$ & $\begin{array}{c}3.497 \\
(2.421)\end{array}$ & $\begin{array}{c}17.38 * * * \\
(6.567)\end{array}$ & $\begin{array}{c}16.76^{* * * *} \\
(6.359)\end{array}$ \\
\hline Female Faculty x Political Science Department & $\begin{array}{c}0.374 \\
(0.267)\end{array}$ & $\begin{array}{l}0.213 \\
(0.255)\end{array}$ & $\begin{array}{c}-0.497^{* *} \\
(0.247)\end{array}$ & $\begin{array}{l}-0.451^{*} \\
(0.243)\end{array}$ & $\begin{array}{l}-1.459 \\
(2.398)\end{array}$ & $\begin{array}{l}-1.674 \\
(2.314)\end{array}$ & $\begin{array}{c}-0.878 \\
(6.299)\end{array}$ & $\begin{array}{l}-1.679 \\
(6.076)\end{array}$ \\
\hline Years Since PhD Degree (log) & $\begin{array}{c}0.514 * * * \\
(0.140)\end{array}$ & $\begin{array}{c}0.467^{* * *} \\
(0.139)\end{array}$ & $\begin{array}{c}0.757 * * * \\
(0.136)\end{array}$ & $\begin{array}{c}0.713 * * * \\
(0.139)\end{array}$ & $\begin{array}{c}4.181 * * * \\
(1.324)\end{array}$ & $\begin{array}{c}3.868^{* * * *} \\
(1.285)\end{array}$ & $\begin{array}{l}8.675 * * \\
(3.478)\end{array}$ & $\begin{array}{l}7.971 * * \\
(3.379)\end{array}$ \\
\hline Years Since PhD Degree $(\log )$ x Economist & $\begin{array}{l}-0.123 \\
(0.172)\end{array}$ & $\begin{array}{l}-0.078 \\
(0.171)\end{array}$ & $\begin{array}{c}0.340 * * \\
(0.165)\end{array}$ & $\begin{array}{c}0.363^{* *} \\
(0.166)\end{array}$ & $\begin{array}{c}4.661 * * * \\
(1.598)\end{array}$ & $\begin{array}{c}4.772 * * * \\
(1.555)\end{array}$ & $\begin{array}{c}12.99 * * * \\
(4.198)\end{array}$ & $\begin{array}{c}13.21 * * * \\
(4.094)\end{array}$ \\
\hline Years Since PhD Degree $(\log )$ x Political Scientist & $\begin{array}{c}0.054 \\
(0.174)\end{array}$ & $\begin{array}{c}0.077 \\
(0.174)\end{array}$ & $\begin{array}{c}0.07 \\
(0.167)\end{array}$ & $\begin{array}{c}0.092 \\
(0.169)\end{array}$ & $\begin{array}{c}1.955 \\
(1.620)\end{array}$ & $\begin{array}{c}2.095 \\
(1.580)\end{array}$ & $\begin{array}{c}4.872 \\
(4.257)\end{array}$ & $\begin{array}{c}5.155 \\
(4.149)\end{array}$ \\
\hline Associate Professor & $\begin{array}{l}-0.175 \\
(0.220)\end{array}$ & $\begin{array}{l}-0.073 \\
(0.209)\end{array}$ & $\begin{array}{c}1.010^{* * *} \\
(0.185)\end{array}$ & $\begin{array}{c}1.055^{* * *} \\
(0.184)\end{array}$ & $\begin{array}{c}2.604 \\
(1.798)\end{array}$ & $\begin{array}{l}2.993^{*} \\
(1.730)\end{array}$ & $\begin{array}{c}2.675 \\
(4.722)\end{array}$ & $\begin{array}{c}3.306 \\
(4.546)\end{array}$ \\
\hline Associate Professor x Economist & $\begin{array}{l}-0.298 \\
(0.280)\end{array}$ & $\begin{array}{l}-0.450^{*} \\
(0.271)\end{array}$ & $\begin{array}{l}-0.382^{*} \\
(0.230)\end{array}$ & $\begin{array}{l}-0.391^{*} \\
(0.228)\end{array}$ & $\begin{array}{l}-4.001^{*} \\
(2.229)\end{array}$ & $\begin{array}{l}-4.201^{*} \\
(2.160)\end{array}$ & $\begin{array}{c}-12.89^{* *} \\
(5.856)\end{array}$ & $\begin{array}{c}-13.14 * * \\
(5.677)\end{array}$ \\
\hline Associate Professor $\mathrm{x}$ Political Scientist & $\begin{array}{l}-0.131 \\
(0.273)\end{array}$ & $\begin{array}{l}-0.197 \\
(0.263)\end{array}$ & $\begin{array}{l}-0.363 \\
(0.230)\end{array}$ & $\begin{array}{l}-0.393^{*} \\
(0.228)\end{array}$ & $\begin{array}{l}-3.068 \\
(2.234)\end{array}$ & $\begin{array}{l}-3.443 \\
(2.154)\end{array}$ & $\begin{array}{c}-8.051 \\
(5.869)\end{array}$ & $\begin{array}{l}-8.691 \\
(5.657)\end{array}$ \\
\hline Full Professor & $\begin{array}{l}-0.543^{*} \\
(0.293)\end{array}$ & $\begin{array}{l}-0.405 \\
(0.284)\end{array}$ & $\begin{array}{c}1.639 * * * \\
(0.267)\end{array}$ & $\begin{array}{c}1.711^{* * *} \\
(0.267)\end{array}$ & $\begin{array}{c}12.80^{* * *} \\
(2.595)\end{array}$ & $\begin{array}{c}13.42^{* * *} \\
(2.498)\end{array}$ & $\begin{array}{c}26.32 * * * \\
(6.816)\end{array}$ & $\begin{array}{c}27.56^{* * * *} \\
(6.569)\end{array}$ \\
\hline Full Professor $\mathrm{x}$ Economist & $\begin{array}{l}-0.0898 \\
(0.355)\end{array}$ & $\begin{array}{l}-0.255 \\
(0.347)\end{array}$ & $\begin{array}{l}-0.234 \\
(0.316)\end{array}$ & $\begin{array}{l}-0.276 \\
(0.315)\end{array}$ & $\begin{array}{l}-4.186 \\
(3.068)\end{array}$ & $\begin{array}{l}-4.701 \\
(2.966)\end{array}$ & $\begin{array}{l}-15.37^{*} \\
(8.059)\end{array}$ & $\begin{array}{c}-16.52^{* *} \\
(7.802)\end{array}$ \\
\hline Full Professor x Political Scientist & $\begin{array}{c}0.07 \\
(0.355)\end{array}$ & $\begin{array}{l}0.0253 \\
(0.347)\end{array}$ & $\begin{array}{l}-0.255 \\
(0.319)\end{array}$ & $\begin{array}{l}-0.272 \\
(0.318)\end{array}$ & $\begin{array}{l}-5.950^{*} \\
(3.093)\end{array}$ & $\begin{array}{c}-6.242 * * \\
(2.996)\end{array}$ & $\begin{array}{c}-17.33^{* *} \\
(8.125)\end{array}$ & $\begin{array}{c}-17.88^{* *} \\
(7.869)\end{array}$ \\
\hline Constant & $\begin{array}{c}-0.895^{* *} \\
(0.367)\end{array}$ & $\begin{array}{c}-0.822 * * \\
(0.329)\end{array}$ & $\begin{array}{c}4.060^{* * *} \\
(0.250)\end{array}$ & $\begin{array}{c}4.119^{* * *} \\
(0.252)\end{array}$ & $\begin{array}{c}2.45 \\
(2.428)\end{array}$ & $\begin{array}{c}2.812 \\
(2.353)\end{array}$ & $\begin{array}{l}-2.428 \\
(6.377)\end{array}$ & $\begin{array}{l}-1.379 \\
(6.185)\end{array}$ \\
\hline F-test: Female and All Interactions & & & $\mathrm{F}(5,1211)=3.37$ & $\mathrm{~F}(5,1284)=2.63$ & $\mathrm{~F}(5,1211)=3.29$ & $\mathrm{~F}(5,1284)=3.21$ & $\mathrm{~F}(5,1211)=4.66$ & $\mathrm{~F}(5,1284)=4.71$ \\
\hline P-values & & & $\mathrm{p}=0.005$ & $\mathrm{p}=0.020$ & $\mathrm{p}=0.006$ & $\mathrm{p}=0.007$ & $\mathrm{p}=0.003$ & $\mathrm{p}=0.003$ \\
\hline University Fixed Effects & Yes & Yes & Yes & Yes & Yes & Yes & Yes & Yes \\
\hline Imputated Data & No & Yes & No & Yes & No & Yes & No & Yes \\
\hline Number of Imputated Interations & -- & 100 & -- & 100 & -- & 100 & -- & 100 \\
\hline No. Observations & 1,981 & 2,152 & 1,262 & 1,337 & 1,262 & 1,337 & 1,262 & 1,337 \\
\hline Adjusted $\mathrm{R}^{2}$ & -- & -- & 0.71 & -- & 0.57 & -- & 0.46 & -- \\
\hline
\end{tabular}

Notes: Standard errors (shown in parentheses). The ommitted comparison category for professor's rank is Assistant Professor. For each model reported in column (2), the variables "Years Since PhD Degree (log)" and corresponding interaction terms were imputed with 100 iterations. See Appendix 1 for detailed description of variables listed in Table $4 . * * *, * * *$ denotes statistical significant at the 1 percent, 5 percent, 10 percent levels, respectively. 
Table 5: OLS Regression Results - Hedonic Wage Models with Citation Measures

\begin{tabular}{|c|c|c|c|c|c|c|}
\hline & (1) & $(2)$ & (3) & $(4)$ & $(\overline{2(5)}$ & (6) \\
\hline Economics Department & $\begin{array}{c}0.210^{* * *} \\
(0.029)\end{array}$ & $\begin{array}{c}0.168^{* * *} \\
(0.028)\end{array}$ & $\begin{array}{c}0.159 * * * \\
(0.027)\end{array}$ & $\begin{array}{c}0.179 * * * \\
(0.027)\end{array}$ & $\begin{array}{c}0.187 * * * \\
(0.028)\end{array}$ & $\begin{array}{l}0.190^{* * * *} \\
(0.0303)\end{array}$ \\
\hline Political Science Department & $\begin{array}{c}-0.0679 * * \\
(0.030)\end{array}$ & $\begin{array}{c}-0.100 * * * \\
(0.026)\end{array}$ & $\begin{array}{c}-0.104 * * * \\
(0.026)\end{array}$ & $\begin{array}{c}-0.100 * * * \\
(0.026)\end{array}$ & $\begin{array}{c}-0.103 * * * \\
(0.026)\end{array}$ & $\begin{array}{c}-0.0874 * * * \\
(0.0292)\end{array}$ \\
\hline Economist & $\begin{array}{c}0.173 * * \\
(0.080)\end{array}$ & $\begin{array}{c}0.295^{* * *} \\
(0.068)\end{array}$ & $\begin{array}{c}0.278 * * * \\
(0.068)\end{array}$ & $\begin{array}{c}0.286^{* * *} \\
(0.068)\end{array}$ & $\begin{array}{c}0.267^{* * *} \\
(0.068)\end{array}$ & $\begin{array}{l}0.299 * * * \\
(0.0680)\end{array}$ \\
\hline Political Scientist & $\begin{array}{l}-0.110 \\
(0.080)\end{array}$ & $\begin{array}{l}-0.041 \\
(0.068)\end{array}$ & $\begin{array}{l}-0.058 \\
(0.068)\end{array}$ & $\begin{array}{l}-0.037 \\
(0.068)\end{array}$ & $\begin{array}{l}-0.040 \\
(0.068)\end{array}$ & $\begin{array}{l}-0.0379 \\
(0.0680)\end{array}$ \\
\hline Female Faculty & $\begin{array}{c}-0.0675^{* *} \\
(0.030)\end{array}$ & $\begin{array}{c}-0.0438^{*} \\
(0.026)\end{array}$ & $\begin{array}{l}-0.0434 \\
(0.027)\end{array}$ & $\begin{array}{c}-0.0432 \\
(0.026)\end{array}$ & $\begin{array}{l}-0.0427 \\
(0.027)\end{array}$ & $\begin{array}{l}-0.0450^{*} \\
(0.0265)\end{array}$ \\
\hline Female Faculty $x$ Economis 1 & $\begin{array}{c}0.016 \\
(0.039)\end{array}$ & $\begin{array}{c}0.028 \\
(0.035)\end{array}$ & $\begin{array}{c}0.015 \\
(0.035)\end{array}$ & $\begin{array}{c}0.032 \\
(0.034)\end{array}$ & $\begin{array}{c}0.032 \\
(0.035)\end{array}$ & $\begin{array}{c}0.0294 \\
(0.0346)\end{array}$ \\
\hline Female Faculty $\mathrm{x}$ Political Scientist & $\begin{array}{c}0.0756^{* *} \\
(0.037)\end{array}$ & $\begin{array}{l}0.0212 \\
(0.033)\end{array}$ & $\begin{array}{l}0.0197 \\
(0.033)\end{array}$ & $\begin{array}{l}0.0159 \\
(0.033)\end{array}$ & $\begin{array}{l}0.00837 \\
(0.033)\end{array}$ & $\begin{array}{c}0.0224 \\
(0.0327)\end{array}$ \\
\hline Years Since PhD Degree (log) & $\begin{array}{c}-0.00922 \\
(0.034)\end{array}$ & $\begin{array}{c}-0.0547 * * \\
(0.028)\end{array}$ & $\begin{array}{c}-0.0546^{*} \\
(0.028)\end{array}$ & $\begin{array}{l}-0.0428 \\
(0.027)\end{array}$ & $\begin{array}{l}-0.026 \\
(0.027)\end{array}$ & $\begin{array}{c}-0.0538^{*} \\
(0.0276)\end{array}$ \\
\hline Years Since PhD Degree $(\log ) \mathrm{x}$ Economist & $\begin{array}{l}-0.0609 \\
(0.040)\end{array}$ & $\begin{array}{c}-0.0981 * * * \\
(0.033)\end{array}$ & $\begin{array}{c}-0.0891 * * * \\
(0.033)\end{array}$ & $\begin{array}{c}-0.101 * * * \\
(0.033)\end{array}$ & $\begin{array}{c}-0.0986^{* * * *} \\
(0.033)\end{array}$ & $\begin{array}{c}-0.0963 * * * \\
(0.0327)\end{array}$ \\
\hline Years Since PhD Degree $(\log )$ x Political Scientist & $\begin{array}{l}0.0452 \\
(0.041)\end{array}$ & $\begin{array}{l}0.0384 \\
(0.033)\end{array}$ & $\begin{array}{l}0.0438 \\
(0.033)\end{array}$ & $\begin{array}{l}0.0362 \\
(0.033)\end{array}$ & $\begin{array}{c}0.036 \\
(0.033)\end{array}$ & $\begin{array}{c}0.0375 \\
(0.0330)\end{array}$ \\
\hline Associate Professor & $\begin{array}{c}0.180 * * * \\
(0.046)\end{array}$ & $\begin{array}{c}0.241 * * * \\
(0.042)\end{array}$ & $\begin{array}{c}0.225 * * * \\
(0.042)\end{array}$ & $\begin{array}{c}0.253 * * * \\
(0.041)\end{array}$ & $\begin{array}{c}0.262 * * * \\
(0.042)\end{array}$ & $\begin{array}{l}0.240 * * * \\
(0.0416)\end{array}$ \\
\hline Associate Professor x Economist & $\begin{array}{l}0.0508 \\
(0.056)\end{array}$ & $\begin{array}{l}0.0237 \\
(0.052)\end{array}$ & $\begin{array}{l}0.0212 \\
(0.053)\end{array}$ & $\begin{array}{l}0.0275 \\
(0.052)\end{array}$ & $\begin{array}{l}0.0302 \\
(0.053)\end{array}$ & $\begin{array}{c}0.0206 \\
(0.0523)\end{array}$ \\
\hline Associate Professor $\mathrm{x}$ Political Scientist & $\begin{array}{l}-0.0824 \\
(0.056)\end{array}$ & $\begin{array}{c}-0.110^{* *} \\
(0.051)\end{array}$ & $\begin{array}{c}-0.112^{* *} \\
(0.052)\end{array}$ & $\begin{array}{c}-0.109 * * \\
(0.052)\end{array}$ & $\begin{array}{c}-0.110^{* *} \\
(0.052)\end{array}$ & $\begin{array}{l}-0.109 * * \\
(0.0514)\end{array}$ \\
\hline Full Professor & $\begin{array}{c}0.385^{* * *} * \\
(0.066)\end{array}$ & $\begin{array}{c}0.489 * * * \\
(0.056)\end{array}$ & $\begin{array}{c}0.497 * * * \\
(0.057)\end{array}$ & $\begin{array}{c}0.501 * * * \\
(0.056)\end{array}$ & $\begin{array}{c}0.520 * * * \\
(0.056)\end{array}$ & $\begin{array}{l}0.490^{* * * *} \\
(0.0559)\end{array}$ \\
\hline Full Professor x Economist & $\begin{array}{c}0.104 \\
(0.077)\end{array}$ & $\begin{array}{l}0.0936 \\
(0.067)\end{array}$ & $\begin{array}{c}0.093 \\
(0.068)\end{array}$ & $\begin{array}{c}0.102 \\
(0.067)\end{array}$ & $\begin{array}{l}0.112 * \\
(0.068)\end{array}$ & $\begin{array}{c}0.0873 \\
(0.0670)\end{array}$ \\
\hline Full Professor x Political Scientist & $\begin{array}{l}-0.0263 \\
(0.078)\end{array}$ & $\begin{array}{l}-0.053 \\
(0.067)\end{array}$ & $\begin{array}{l}-0.0647 \\
(0.068)\end{array}$ & $\begin{array}{l}-0.0462 \\
(0.068)\end{array}$ & $\begin{array}{l}-0.0436 \\
(0.068)\end{array}$ & $\begin{array}{l}-0.0532 \\
(0.0675)\end{array}$ \\
\hline Google Scholar's Total Citation Count (log) & $\begin{array}{l}0.0178^{*} \\
(0.009)\end{array}$ & $\begin{array}{l}0.0154 \\
(0.011)\end{array}$ & $\begin{array}{c}0.0592 * * * \\
(0.008)\end{array}$ & & & $\begin{array}{c}0.0155 \\
(0.0107)\end{array}$ \\
\hline Google Scholar's h-index & $\begin{array}{c}0.0102 * * * \\
-0.0021\end{array}$ & $\begin{array}{c}0.00996^{* * * *} \\
-0.00237\end{array}$ & & $\begin{array}{c}0.00752^{* * * *} \\
-0.000805\end{array}$ & & $\begin{array}{c}0.00982 * * * \\
(0.00238)\end{array}$ \\
\hline Google Scholar's i10-index & $\begin{array}{c}-0.00176^{* *} \\
(0.0007)\end{array}$ & $\begin{array}{c}-0.00145^{*} \\
(0.0008)\end{array}$ & & & $\begin{array}{c}0.00237 * * * \\
(0.0003)\end{array}$ & $\begin{array}{l}-0.00141^{*} \\
(0.000802)\end{array}$ \\
\hline US News Ranking in Economics x Econ Dept. & & & & & & $\begin{array}{l}-0.000397^{*} \\
(0.000226)\end{array}$ \\
\hline US News Ranking in Political Science x Poli Sci Dept. & & & & & & $\begin{array}{l}-0.000145 \\
(0.000239)\end{array}$ \\
\hline Constant & $\begin{array}{c}11.34 * * * \\
(0.071)\end{array}$ & $\begin{array}{c}11.39 * * * \\
(0.065)\end{array}$ & $\begin{array}{c}11.23 * * * \\
(0.061)\end{array}$ & $\begin{array}{c}11.46^{* * *} \\
(0.052)\end{array}$ & $\begin{array}{c}11.47 * * * \\
(0.052)\end{array}$ & $\begin{array}{l}11.38^{* * *} \\
(0.0651)\end{array}$ \\
\hline F-test: Female and All Interactions & $\mathrm{F}(3,1210)=2.95$ & $\mathrm{~F}(3,1919.7)=1.46$ & $F(3,1926.6)=1.77$ & $\mathrm{~F}(3,1923.3)=1.51$ & $\mathrm{~F}(3,1926.6)=1.80$ & $\mathrm{~F}(3,1915.7)=1.46$ \\
\hline P-values & $\mathrm{p}=0.03$ & $\mathrm{p}=0.22$ & $\mathrm{p}=0.15$ & $\mathrm{p}=0.21$ & $\mathrm{p}=0.14$ & $\mathrm{p}=0.22$ \\
\hline University Fixed Effects & Yes & Yes & Yes & Yes & Yes & Yes \\
\hline Imputated Data & No & Yes & Yes & Yes & Yes & Yes \\
\hline Number of Imputated Interations & -- & 100 & 100 & 100 & 100 & 100 \\
\hline No. Observations & 1,262 & 1,981 & 1,981 & 1,981 & 1,981 & 1,981 \\
\hline
\end{tabular}

Notes: Standard errors (shown in parentheses). The ommitted comparison category for faculty's rank is Assistant Professor. For columns (2)-(6), the variables Years Since PhD Degree (log), Google Scholar's Total Citation Count, hindex, and i10-index were imputed with 100 iterations. See Appendix 1 for detailed description of variables listed in Table $5 .{ }^{* * *},{ }^{* *}, *$ denotes statistical significant at the 1 percent, 5 percent, 10 percent levels, respectively. 
Table 6: OLS Regression Results - Differential Returns to Citations (Google Scholar's Total Citation Count) by Gender and Field

\begin{tabular}{|c|c|c|c|c|c|c|}
\hline & \multicolumn{2}{|c|}{ Panel A: By Gender } & \multicolumn{2}{|c|}{ Panel B: By Field } & \multicolumn{2}{|c|}{ Panel C: By Gender and Field } \\
\hline & (1) & (2) & (1) & $(2)$ & (1) & (2) \\
\hline Economics Department & $0.205^{* * *}$ & $0.159 * * *$ & $0.211 * * *$ & $0.165^{* * *}$ & $0.209 * * *$ & $0.163 * * *$ \\
\hline & $(0.030)$ & $(0.027)$ & $(0.029)$ & $(0.027)$ & $(0.029)$ & $(0.027)$ \\
\hline Political Science Department & $\begin{array}{c}-0.0750^{* *} \\
(0.031)\end{array}$ & $\begin{array}{c}-0.108^{* * *} \\
(0.026)\end{array}$ & $\begin{array}{c}-0.0740 * * \\
(0.030)\end{array}$ & $\begin{array}{c}-0.106^{* * *} \\
(0.026)\end{array}$ & $\begin{array}{c}-0.0820^{* * *} \\
(0.030)\end{array}$ & $\begin{array}{c}-0.113^{* * *} \\
(0.026)\end{array}$ \\
\hline Economist & $\begin{array}{c}0.173^{* *} \\
(0.082)\end{array}$ & $\begin{array}{c}0.298^{* * *} \\
(0.069)\end{array}$ & $\begin{array}{l}-0.137 \\
(0.100)\end{array}$ & $\begin{array}{l}0.0474 \\
(0.094)\end{array}$ & $\begin{array}{l}-0.167 \\
(0.114)\end{array}$ & $\begin{array}{c}0.055 \\
(0.109)\end{array}$ \\
\hline Political Scientist & $\begin{array}{l}-0.118 \\
(0.082)\end{array}$ & $\begin{array}{r}-0.0463 \\
(0.069)\end{array}$ & $\begin{array}{c}-0.343^{* * *} \\
(0.101)\end{array}$ & $\begin{array}{c}-0.203 * * \\
(0.095)\end{array}$ & $\begin{array}{c}-0.462 * * * \\
(0.119)\end{array}$ & $\begin{array}{c}-0.270 * * \\
(0.114)\end{array}$ \\
\hline Female Faculty & $\begin{array}{l}0.0492 \\
(0.068)\end{array}$ & $\begin{array}{l}0.0784 \\
(0.070)\end{array}$ & $\begin{array}{c}-0.0688^{* *} \\
(0.030)\end{array}$ & $\begin{array}{c}-0.0479 * \\
(0.027)\end{array}$ & $\begin{array}{l}-0.145 \\
(0.120)\end{array}$ & $\begin{array}{l}-0.0431 \\
(0.129)\end{array}$ \\
\hline Female Faculty x Economis 1 & $\begin{array}{c}0.00707 \\
(0.039)\end{array}$ & $\begin{array}{l}0.0186 \\
(0.035)\end{array}$ & $\begin{array}{c}0.00822 \\
(0.039)\end{array}$ & $\begin{array}{l}0.0217 \\
(0.035)\end{array}$ & $\begin{array}{l}0.0711 \\
(0.160)\end{array}$ & $\begin{array}{c}-0.00653 \\
(0.172)\end{array}$ \\
\hline Female Faculty x Political Scientist & $\begin{array}{c}0.0695^{*} \\
(0.038)\end{array}$ & $\begin{array}{l}0.0166 \\
(0.033)\end{array}$ & $\begin{array}{c}0.0765^{* *} \\
(0.038)\end{array}$ & $\begin{array}{l}0.0248 \\
(0.033)\end{array}$ & $\begin{array}{c}0.422 * * * \\
(0.155)\end{array}$ & $\begin{array}{l}0.292^{*} \\
(0.167)\end{array}$ \\
\hline Google Scholar's Total Citation Count (log) & $\begin{array}{c}0.0639 * * * \\
(0.008)\end{array}$ & $\begin{array}{c}0.0645^{* * *} \\
(0.009)\end{array}$ & $\begin{array}{c}0.00186 \\
(0.014)\end{array}$ & $\begin{array}{l}0.0179 \\
(0.016)\end{array}$ & $\begin{array}{l}-0.0032 \\
(0.016)\end{array}$ & $\begin{array}{l}0.0185 \\
(0.019)\end{array}$ \\
\hline Female Faculty x Total Citation Count (log) & $\begin{array}{c}-0.0175^{*} \\
(0.009)\end{array}$ & $\begin{array}{c}-0.0187^{*} \\
(0.010)\end{array}$ & & & $\begin{array}{l}0.0117 \\
(0.018)\end{array}$ & $\begin{array}{c}-0.000772 \\
(0.019)\end{array}$ \\
\hline Economist $\mathrm{x}$ Total Citation Count $(\log )$ & & & $\begin{array}{c}0.0812 * * * \\
(0.017)\end{array}$ & $\begin{array}{c}0.0674 * * * \\
(0.019)\end{array}$ & $\begin{array}{c}0.0863^{* * * *} \\
(0.019)\end{array}$ & $\begin{array}{c}0.0666^{* * * *} \\
(0.021)\end{array}$ \\
\hline Political Scientist x Total Citation Count $(\log )$ & & & $\begin{array}{c}0.0605 * * * \\
(0.017)\end{array}$ & $\begin{array}{c}0.0422 * * \\
(0.019)\end{array}$ & $\begin{array}{c}0.0803^{* * *} \\
(0.019)\end{array}$ & $\begin{array}{c}0.0555^{* *} \\
(0.022)\end{array}$ \\
\hline Female $\mathrm{x}$ Economist $\mathrm{x}$ Total Citation Count (log) & & & & & $\begin{array}{r}-0.0095 \\
(0.024)\end{array}$ & $\begin{array}{c}0.00432 \\
(0.025)\end{array}$ \\
\hline Female x Political Scientist x Total Citation Count (log) & & & & & $\begin{array}{c}-0.0538^{* *} \\
(0.023)\end{array}$ & $\begin{array}{c}-0.0418^{*} \\
(0.025)\end{array}$ \\
\hline Constant & $\begin{array}{c}11.16 * * * \\
(0.073)\end{array}$ & $\begin{array}{c}11.19 * * * \\
(0.065)\end{array}$ & $\begin{array}{c}11.40^{* * * *} \\
(0.080)\end{array}$ & $\begin{array}{c}11.37 * * * \\
(0.078)\end{array}$ & $\begin{array}{c}11.44 * * * \\
(0.096)\end{array}$ & $\begin{array}{c}11.37 * * * \\
(0.096)\end{array}$ \\
\hline F-test: Female and All Interactions & $\mathrm{F}(4,1211)=2.11$ & $\mathrm{~F}(4,1914.3)=1.22$ & $\mathrm{~F}(3,1210)=2.63$ & $\mathrm{~F}(3,1920.8)=1.44$ & $\mathrm{~F}(6,1207)=2.39$ & $\mathrm{~F}(6,1902.8)=1.58$ \\
\hline P-values & $\mathrm{p}=0.08$ & $\mathrm{p}=0.30$ & $\mathrm{p}=0.05$ & $\mathrm{p}=0.23$ & $\mathrm{p}=0.03$ & $\mathrm{p}=0.15$ \\
\hline University Fixed Effects & Yes & Yes & Yes & Yes & Yes & Yes \\
\hline Faculty Characteristic Controls ${ }^{\mathrm{a}}$ & Yes & Yes & Yes & Yes & Yes & Yes \\
\hline Imputated Data & No & Yes & No & Yes & No & Yes \\
\hline Number of Imputated Interations & -- & 100 & -- & 100 & -- & 100 \\
\hline No. Observations & 1,262 & 1,981 & 1,262 & 1,981 & 1,262 & 1,916 \\
\hline Adjusted $\mathrm{R}^{2}$ & 0.698 & -- & 0.703 & -- & 0.705 & - \\
\hline
\end{tabular}

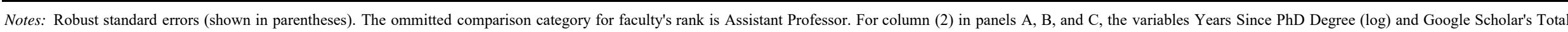

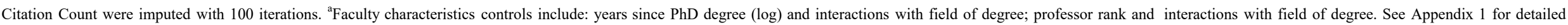
description of variables listed in Table $6 .{ }^{* * *},{ }^{* *},{ }^{*}$ denotes statistical significant at the 1 percent, 5 percent, 10 percent levels, respectively. 


\begin{tabular}{|c|c|}
\hline Variable Type & Variable Description \\
\hline Annual Salary Compensation (log) & $\begin{array}{l}\text { Dependent Variable: Annual salary in current dollars, as } \\
\text { publicly reported by the respective institutions of higher } \\
\text { education (IHEs). In cases where multiple salary figures } \\
\text { were available, this indicator was full-time equivalent } \\
\text { salary including reported benefits. The data represent the } \\
\text { most recent reporting year as of July } 2018 \text { (which in most } \\
\text { cases was 2017). Inconsistencies in reporting necessitate } \\
\text { the use of IHE fixed effects for all salary models. }\end{array}$ \\
\hline \multirow[t]{3}{*}{ Departmental Affiliation Indicators } & School Public Affairs (omitted category) \\
\hline & Economics \\
\hline & Political Science \\
\hline \multirow[t]{3}{*}{ Degree Field Indicators } & Other Fields (omitted category) \\
\hline & Economics \\
\hline & Political Science \\
\hline \multirow[t]{2}{*}{ Gender Indicators } & Male Faculty (omitted category) \\
\hline & Female Faculty \\
\hline \multirow[t]{3}{*}{ Rank Indicators } & Assistant Professor (omitted category) \\
\hline & Associate Professor \\
\hline & Full Professor \\
\hline Experience & Years Since PhD Degree (log) \\
\hline \multirow[t]{3}{*}{ Productivity Measures } & $\underline{\text { Total Citation Count }}$ : Total number of citations. \\
\hline & $\begin{array}{l}\text { h-index } \text { : Characterizes faculty's productity in the field by } \\
\text { combining both the breadth and depth of impact of their } \\
\text { scholarly work (Hamermesh, 2018). The h-index is } \\
\text { calculated by counting the number of publications for } \\
\text { which a scholar has been cited by other scholars at least } \\
\text { that same number of times. For example, a h-index of } 16 \\
\text { means that the scholar has published at least } 16 \text { papers } \\
\text { that have each been cited at least } 16 \text { times. }\end{array}$ \\
\hline & $\begin{array}{l}\text { i10-index }: \text { Measures the number of papers with at least } \\
10 \text { citations. For example, an } 110 \text {-index of } 12 \text { means that } \\
12 \text { publications of the scholar have each been cited at least } \\
10 \text { times. }\end{array}$ \\
\hline
\end{tabular}

Notes: The productivity measures are from each faculty's Google Scholar profile as of November 2018. "Other Fields" include other fields whose faculty members are in the school of public affairs, such as, sociology, demography, anthropology, etc.

Source: Publicly available data collected from a variety of sources. 
Appendix 2: List of Institution Names by Alphabetical Order

\begin{tabular}{|c|c|c|c|}
\hline & Name of Institution & $\begin{array}{c}\text { No. of } \\
\text { Faculty } \\
\text { Members }\end{array}$ & $\begin{array}{c}\text { Percent of } \\
\text { Faculty } \\
\text { Members }\end{array}$ \\
\hline 1 & Arizona State University & 68 & 3.16 \\
\hline 2 & Baruch College & 80 & 3.72 \\
\hline 3 & Florida State University & 52 & 2.42 \\
\hline 4 & Georgia Institute of Technology & 39 & 1.81 \\
\hline 5 & George Mason University & 91 & 4.23 \\
\hline 6 & Georgia State University & 80 & 3.72 \\
\hline 7 & Indiana University Bloomington & 96 & 4.46 \\
\hline 8 & John Jay College & 46 & 2.14 \\
\hline 9 & North Carolina State University & 42 & 1.95 \\
\hline 10 & Ohio State University & 73 & 3.39 \\
\hline 11 & Rutgers University - Newark & 49 & 2.28 \\
\hline 12 & Texas A\&M University - College Station & 93 & 4.32 \\
\hline 13 & University at Albany - State University of New York (SUNY) & 52 & 2.42 \\
\hline 14 & University of Arizona & 47 & 2.18 \\
\hline 15 & University of California - Berkeley & 89 & 4.14 \\
\hline 16 & University of California - Los Angeles & 129 & 5.99 \\
\hline 17 & University of Central Florida & 63 & 2.93 \\
\hline 18 & University of Colorado - Denver & 41 & 1.91 \\
\hline 19 & University of Georgia & 52 & 2.42 \\
\hline 20 & University of Illinois - Chicago & 39 & 1.81 \\
\hline 21 & University of Kansas & 37 & 1.72 \\
\hline 22 & University of Kentucky & 29 & 1.35 \\
\hline 23 & University of Maryland - College Park & 71 & 3.3 \\
\hline 24 & University of Michigan & 113 & 5.25 \\
\hline 25 & University of Minnesota & 72 & 3.35 \\
\hline 26 & University of Missouri - Columbia & 35 & 1.63 \\
\hline 27 & University of Nebraska - Omaha & 30 & 1.39 \\
\hline 28 & University of North Carolina - Chapel Hill & 62 & 2.88 \\
\hline 29 & University of Texas - Austin & 100 & 4.65 \\
\hline 30 & University of Virginia & 94 & 4.37 \\
\hline 31 & University of Washington & 73 & 3.39 \\
\hline 32 & University of Wisconsin - Madison & 71 & 3.30 \\
\hline \multirow[t]{2}{*}{33} & Virginia Commonwealth University & 44 & 2.04 \\
\hline & No. Observations & 2,152 & 100.00 \\
\hline
\end{tabular}

Source: Authors' calculations. 